\title{
Temporal and Spatial Accretion Patterns and the Impact of Livestock Grazing in a Restored Coastal Salt Marsh
}

\author{
E. C. Koppenaal ${ }^{1}$ - P. Esselink ${ }^{1,2}$ (D) W. E. van Duin ${ }^{3,4}$. J. P. Bakker ${ }^{1}$ (D
}

Received: 18 November 2020 / Revised: 23 March 2021 / Accepted: 23 May 2021 / Published online: 24 July 2021

(c) The Author(s) 2021

\begin{abstract}
A summer polder had developed a deficit in surface elevation of about $20 \mathrm{~cm}$ in respect to rising sea level during its almost one-hundred-year period of embankment. We addressed the questions whether the distance of the restored site to the intertidal flats and continuation of livestock grazing in the restored site could hamper surface-elevation change during the first 10 years after de-embankment of the summer polder. The surface-elevation change showed similar positive linear relationships with annual tidal flooding in both the reference salt marsh and the restored site, indicating that the surface-elevation change in the restored site was not moderated by the distance from the sea. The surface-elevation change had a clear seasonal pattern with positive values in winter and negative values during summer. The surface-elevation change was $11 \mathrm{~mm} / \mathrm{year}$ in the grazed reference salt marsh and $7 \mathrm{~mm} /$ year in the grazed restored site, but amounted to $17 \mathrm{~mm} /$ year in ungrazed exclosures in the restored site, showing that grazing retarded the catching up of the elevation deficit in the restored site. The surface-elevation change within the restored site was higher close to the constructed creeks indicating the inception of levee formation. The surface-elevation change was also positively affected by the proximity of breaches in the embankment, but this effect was less clear than the effect of creeks. We conclude that the surface-elevation deficit may be compensated in the Wadden Sea summer polders by their de-embankment when sediment supply is high, whereas livestock grazing retards this process. Dug creeks increase spatial variation in the restored site.
\end{abstract}

Keywords Coastal realignment · Grazing $\cdot$ Salt-marsh restoration · Sediment supply $\cdot$ Surface-elevation change

\section{Introduction}

Coastal salt marshes are broadly defined as areas vegetated by herbs, grasses or low shrubs, which are subject to periodic flooding as a result of fluctuations in the level of the adjacent water

Communicated by Eduardo Siegle

J. P. Bakker

j.p.bakker@rug.nl

P. Esselink

peter.puccimar@gmail.com

1 Conservation Ecology Group, Groningen Institute of Evolutionary Life Sciences (GELIFES), University of Groningen, PO Box 11103, 9700 CC Groningen, The Netherlands

2 Puccimar Ecological Research \& Consultancy, Boermarke 35, Vries, HD 9481, The Netherlands

3 Wageningen Marine Research, Wageningen University \& Research, PO Box 57, 1780 AB Den Helder, The Netherlands

4 Artemisia-kwelderonderzoek, Den Helder, The Netherlands bodies (Adam 1990). Salt marshes are sedimentary environments, susceptible to change in relative sea level. Their existence reflects the interplay between geomorphological, physical and biological processes, such as sediment supply, tidal regime, wind and wave patterns and trapping of sediment by the vegetation (Stumpf 1983; Allen 2000; Adam et al. 2008).

European salt marshes, in particular, have experienced a long history of anthropogenic impacts, some of which can be traced back several millennia, including livestock grazing, land claim and lowering of the land surface due to both peat mining and drainage for agriculture (Davy et al. 2009; Vos and Knol 2015). The Wadden Sea, a 500-km-long barrier-lagoon system along the coastline of the Netherlands, Germany and Denmark, and still one of the world's largest coastal wetlands, was almost halved by the medieval embankments of the larger part of its mainland marshes (Reise 2005). For the Dutch sector, Dijkema (1987) showed how the size of the mainland salt marshes was further reduced from about $140 \mathrm{~km}^{2}$ around 1600 down to $25 \mathrm{~km}^{2}$ far into the twentieth century, because the seaward expansion of new marshes could not keep pace with the rate of 
landward loss by embankments. In the Wadden Sea, the era of land claiming has ended, and the Wadden Sea is now managed for its conservation values in a trilateral cooperation between the Netherlands, Germany and Denmark (CWSS 2010).

Over the past few decades, coastal salt marshes have been restored in increasing quantities for the purpose of either coastal defence or ecological restoration, especially in Europe and North America (Wolters et al. 2005a; J. French 2006; Brooks et al. 2015; Zedler 2017). An economic trade-off and the growing awareness that salt marshes contribute to coastal protection by dissipation of tidal energy and wave attenuation (Shepard et al. 2011) caused a partial replacement of costly traditional engineering practices, such as revetment works, by alternative softer approaches. These alternatives mostly involve a landward relocation of the coastal defence line, allowing intertidal habitats including salt marshes, to develop seaward of the new defence line. This landward relocation is now termed managed retreat or coastal realignment (P.W. French 2006; Zedler 2017).

Coastal realignment was triggered by the unplanned reestablishment of salt marshes where sea defences were not repaired after storm breaches (French 1999; Wolters et al. 2005a). Geomorphical and ecological changes following these unintended breaches were often poorly monitored. This lack of monitoring makes it difficult to draw conclusions on sedimentation and re-establishment of salt-marsh communities in these early de-embankments. Furthermore, comparisons with nearby reference salt marshes are not always justified (Wolters et al. 2005a; Mossman et al. 2012a; Zedler 2017).

In the 1990s, it was decided to designate summer polders on the north coast of the Netherlands for salt-marsh restoration and monitor their development. Summer polders are protected from inundation during normal tides by low summer dikes, but they may be flooded during storm tides. In the Wadden Sea, at some coastal stretches of both the Netherlands and Germany, summer polders may be found outside the seawall, but separated from the sea by a salt marsh. This sets these summer polders apart from realignments, which are fully exposed to the sea.

With rising sea level, the persistence of existing salt marshes depends on the balance between sea-level rise and sediment accretion. For salt marshes, the immediate sources of sediment are tidal waters, which mainly provide mineral sediment, and the marsh vegetation itself, which supplies organic matter. European salt marshes are allochthonous, i.e. accretion is generally controlled by sediment deposition from the water column during tidal flooding and enhanced by plants (J. French 2006). Similar processes are found in the southern marshes along the Atlantic coast of North America. In contrast, the northern marshes also show vertical accretion of belowground marsh plant debris, or peat, and are autochthonous (Bertness 1999). Vertical accretion depends on the local tidal range: estuaries are macrotidal with ranges up to $10 \mathrm{~m}$, and water bodies disconnected from the ocean are microtidal with ranges of a few decimetres. The Wadden Sea in the Netherlands is mesotidal with a tidal range of about $2 \mathrm{~m}$. Temporal conditions such as inundation frequency and storm events may contribute significantly to sediment deposition (De Groot et al. 2011). The lower parts of the marsh are more frequently, deeper and also longer inundated than the high marsh and, hence, will increase more in surface elevation (Van Wijnen and Bakker 2001). Several studies reported considerably higher amounts of sediment deposition during storm events than during normal tides (Stumpf 1983; French and Spencer 1993; Van Duin et al. 1997; Allen 2000). Hence, more sediments may be deposited during winter coinciding with the storm season than during summer.

Sedimentation may result in vertical accretion. The latter combines deposition, erosion and autocompaction of sediments, as well as the possible accumulation of organic matter. If the surface of the marsh is measured over time with respect to a fixed benchmark, we refer to the surfaceelevation change (SEC) (Nolte et al. 2013a). Spatial geomorphological features also affect sediment distribution on the salt marsh with higher accretion rates near creeks and the seaward marsh edge (French and Spencer 1993; Cahoon et al. 1995; Esselink et al. 1998; Temmerman et al. 2003; Bartholdy et al. 2010).

In the Wadden Sea, both summer polders and salt marshes were traditionally used for livestock grazing by farmers. If grazing is abandoned in these salt marshes, the vegetation develops rapidly towards late-successional stages dominated by the shrub Atriplex portulacoides and the tall grasses Elytrigia atherica or Phragmites australis in the low, high and brackish marshes, respectively, at the expense of more species-rich plant communities (Bakker et al. 2016). In order to prevent this development, nowadays, livestock grazing is often applied as a tool in the conservation management of the salt marshes. Livestock reduces the canopy height and thereby the surface roughness (Davidson et al. 2017) and hence may affect both sedimentation and marsh accretion negatively (e.g. Leonard 1997). Furthermore, livestock causes compaction of the soil by trampling and hence reduces SEC (Elschot et al. 2013; Schrama et al. 2013; Pagès et al. 2019).

The same factors that control SEC in salt marshes are likely to affect SEC in a managed-retreat site in a similar way. This study focuses on SEC after de-embankment and aims to identify whether grazing and flooding regime are important when considering measures to restore a salt marsh by de-embankment through breaching. The restored site is likely to have a surface-elevation deficit, since many 
tidal inundations were prevented by the embankment which results in a lower elevation than would have occurred without a summer dike (Wolters et al. 2005a). It is therefore necessary to assess:

1. To what extent SEC in a restored site is comparable to that on the adjacent reference salt marsh.

2. How do flooding frequency and the amount of inundating water account for SEC in both the restored site and the reference salt marsh?

3. How do breaches and creeks contribute to the spatial variation of the SEC in the restored site and how is this affected by winter or summer period?

4. What is the effect of livestock grazing on SEC?

\section{Methods}

\section{Study Area}

The study area is part of a c. 3500-ha complex of summer polders and salt marshes in Noord-Friesland Buitendijks, the Netherlands (Fig. 1). The local tidal range is about
$2.3 \mathrm{~m}$. Polders and marshes have a soil with mainly finegrained sediment. Measurements of surface elevation were taken in Dutch Ordnance Level (NAP) and recalculated to mean-high-tide level (MHT). In the study area, MHT was approximately $1.0 \mathrm{~m}$ NAP.

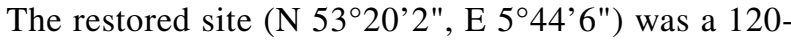
ha summer polder, located between a $1-\mathrm{km}$ wide salt marsh seaward and summer polder landward (Esselink et al. 2015). The restored site was a former salt marsh, embanked in 1909 (Schroor 2009). Managed de-embankment occurred in September 2001. The summer dike (crest height $2.7 \mathrm{~m} \mathrm{NAP}$ ) was breached at three spots, more than $1 \mathrm{~km}$ apart. At each breach of about $10 \mathrm{~m}$, a meandering creek was dug to enhance tidal exchange between the Wadden Sea with the adjacent salt marsh and the restored site (Fig. 1). Older summer polders between the restored site and the seawall remained untouched. The $1-\mathrm{km}$ wide salt marsh in front of the summer polders developed from artificially drained sedimentation fields surrounded by brushwood groynes, which were constructed from the 1930s onward (Dijkema 1983, 1997). A few years before the de-embankment, grazing management in both the salt marsh and the summer polders changed from agricultural
Fig. 1 Map of the study area with the restored site and adjacent seaward reference salt marsh. The area between the restored site and the seawall are remaining summer polders. Furthermore, the map shows the three breaches, dug creeks and 12 measuring stations in the restored site and 6 stations in the reference salt marsh. Exclosures were established near each of the 12 measuring stations in the restored site (online version in colour)

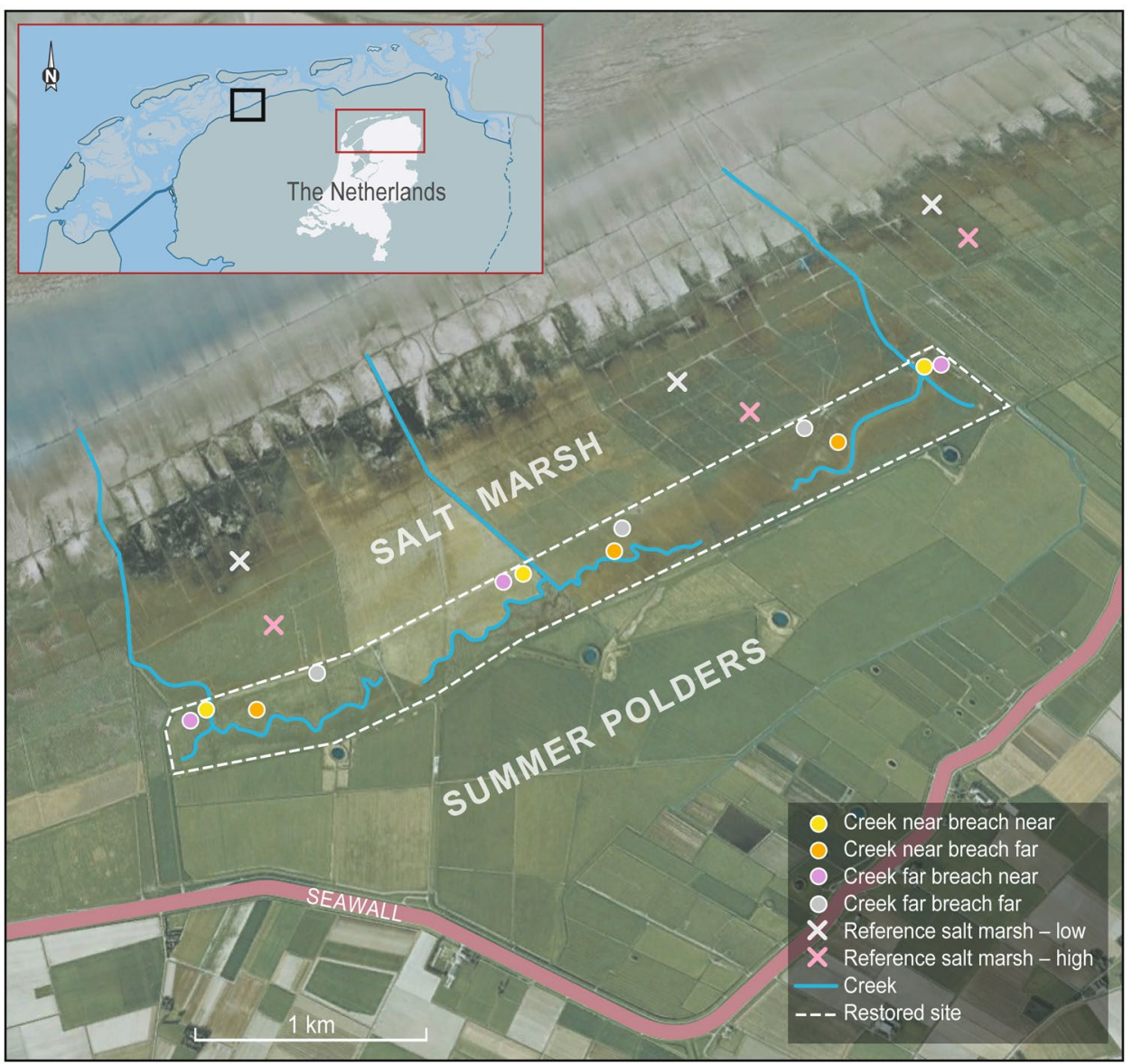


exploitation into grazing for conservation purposes. In the restored site, summer grazing by horses and cattle was continued after breaching the summer dike. The grazing season started in April up to the beginning of June and lasted until 1 October. Stocking densities fluctuated over the years, but generally exceeded the level of 1 LUT/ha. Successive vegetation mapping from before up to 10 years after de-embankment revealed that the area remained vegetation covered, whereas in the meantime, vegetation composition changed from glycophytic grassland into halophytic salt-marsh communities after de-embankment (Esselink et al. 2015; Chang et al. 2016).

\section{SEC Measurements}

SEC was assessed with sedimentation-erosion bar (SEB) measurements (Boumans and Day 1993; Nolte et al. 2013a). A SEB-measuring point consisted of two horizontally aligned upright plastic poles $(\varnothing 7.5 \mathrm{~cm}), 2.0 \mathrm{~m}$ apart with an initial height of $0.3-0.5 \mathrm{~m}$ above the soil surface and with the bottom end in a sandy horizon at a depth of c. $1.2 \mathrm{~m}$.

In order to study the effect of the breaches and the artificial creeks on SEC in the restored site, twelve SEB measuring stations, distributed equally over the three catchment areas, were installed in a stratified design and allocated into four classes in respect to their position in the sedimentsupply route, viz. (a) close to both creek and breach, (b) close to creek but far from breach, (c) far from creek but close to breach and (d) far from both creek and breach (Fig. 1). Since there were three breaches and three creeks, we had three stations for each station class. In order to assess the effect of livestock grazing on SEC in the restored site, at each station, an exclosure $(9 \mathrm{~m} \times 27 \mathrm{~m})$ was established before the start of the first grazing season after deembankment (Veeneklaas et al. 2015). An exclosure is a small area permanently protected against grazing. All 12 stations had six SEB points, three inside and three outside each exclosure.

In order to compare SEC in the restored site and the adjacent reference salt marsh, SEB stations were also installed in the reference salt marsh: three in both the low and high marsh. Contrary to the restored site, no exclosures were constructed, and hence, each SEB station consisted of three grazed replicated SEB points. Thus, in total, we had nine SEB points in both low and high reference salt marshes. At one station, two measuring points were lost due to disturbance. At the start of the monitoring, the height of the SEB poles was calibrated with respect to Dutch Ordnance Level (NAP) and was recalibrated twice during the following 10 years. During measurements, a 2-m-long aluminium bar with 17 holes was placed on the poles, and surface elevation was measured to the nearest $\mathrm{mm}$ by lowering a $50-\mathrm{cm}$-long pin through each of the 17 holes down to the marsh surface. Measurements from the 17 holes were averaged to a single value per SEB point.

SEB points were installed in 2000, i.e. 1 year before deembankment. Before regular monitoring was started in both the restored site and the reference marsh, surface elevation was measured twice (in December 2000 and 2001), i.e. before and after the de-embankment. In the restored site, surface elevation was monitored at a regular basis twice a year during the first 4 years after de-embankment, from March 2002 to August 2005. In addition, surface elevation was assessed again in August 2007 and August 2011 (6 and 10 years after de-embankment). In the reference salt marsh, surface elevation was monitored biannually from March 2002 to August 2011.

\section{Flooding Regime}

Assessing the flooding regime of the study area, we had to rely on two tide gauges at a considerable distance, viz. Harlingen and Lauwersoog, $30 \mathrm{~km}$ west and $30 \mathrm{~km}$ east of the study area, respectively. The tide at these two stations is more or less synchronous, and tide characteristics are very similar (Esselink and Chang 2010). For each high tide, the average tidal height of the two tide gauges was therefore accepted as proxy for the tidal height in the study area. Per $10-\mathrm{cm}$ height class of both the high-tides and the marsh elevation, flooding frequency was calculated per storm year, which we defined from 1 September the year before to 31 August of that given year. Year is considered to be storm year throughout the rest of this paper.

Cumulative height of the water column (CHWC) above the marsh was then calculated for each measuring point by

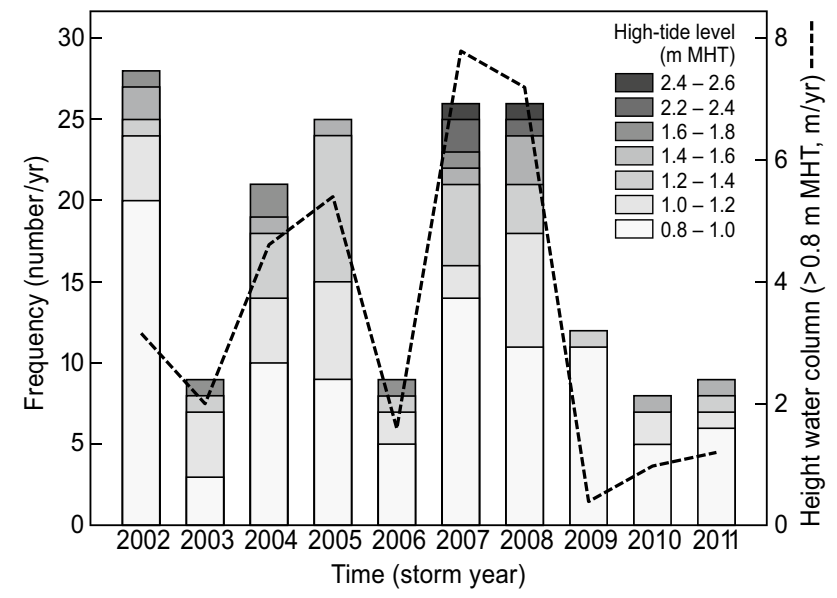

Fig. 2 Annual variation of extreme high tides and the cumulative height of the water column (right axis) during the study period. Storm year is defined as the period 1 September-31 August 
summing up the water depths above the marsh bed of all flooding events in each year. Both flooding frequency and CHWC varied considerably between years. Figure 2 shows the frequency distribution of the tides that exceeded the level of $0.8 \mathrm{~m}$ MHT, which level approximately matches both the upper elevation of the high salt marsh and the highest parts of the restored site in 2001. These tides represent the $2.5 \%$ highest tides during this period. Especially in 2002, 2005, 2007 and 2008, the number of high tides was above average. Two storm surges produced extreme hightide levels of $2.5 \mathrm{~m}$ MHT, viz. on 1 November 2006 and 9 November 2007, significantly contributing to the CHCW of 2007 and 2008, respectively.

\section{Data Analyses}

The data consist of repeated measurements per SEBmeasuring point. Explorative analysis showed that there was a violation of independence and heterogeneity. Furthermore, the data consist of many locations with few samples. Therefore, nonparametric and nonlinear statistical tests were used. A Kruskal-Wallis test was applied to evaluate the influence of station position in the sedimentsupply route on SEC in the restored site (close or far to breach and/or creek, $\mathrm{n}=9$ for each station position). An a posteriori nonparametric alternative of the Tukey test, the Nemenyi multiple comparison test, was applied to evaluate which station positions differed significantly in SEC rates (Zar 1996).

To evaluate the effect of grazing on SEC, a two-sided Mann-Whitney test was applied to year-round, summer and winter SEC inside and outside of the exclosures. The relationship between the annual SEC and flooding frequency per location and the relationship between SEC and CHWC was assessed by a linear least square model. In order to determine the best method, some pre-analyses were carried out, because of dependencies and semicontinuous data. After removal of one outlier in the low marsh, the assumptions of the linear model were met, and the linear models were applied. All analyses were done in R 3.6.2 (2019) with stats-package for the Mann-Whitney test and PMCMR-package for Kruskal-Wallis and Nemenyi tests (Pohlert 2014).

\section{Results}

\section{Surface Elevation and SEC in Restored Site and Reference Salt Marsh}

Based on the SEB measurements in December 2000, 9 months prior to the breaching, surface elevation among the 12 SEB stations in the restoration site ranged from 0.42 to $0.79 \mathrm{~m}$ MHT. Surface elevation varied less between the four classes of stations with average elevations of $0.55 \mathrm{~m}$, $0.49 \mathrm{~m}, 0.61 \mathrm{~m}$ and $0.56 \mathrm{~m} \mathrm{MHT}$ at (a) close to both creek and breach, (b) close to creek and far from breach, (c) far from creek and close to breach and (d) far from both creek and breach, respectively. Based on these measurements, the average surface elevation in the restored site before breaching was $0.55 \mathrm{~m} \mathrm{MHT}$, at that moment more or less comparable to the centre value of the high and low reference salt marshes (average elevation of $0.73 \mathrm{~m}$ MHT and $0.28 \mathrm{~m}$ MHT, respectively). After the breaching of the summer dike, SEC in the restored site exceeded the SEC in the adjacent high reference salt marsh, but was less than the SEC in the low marsh (Fig. 3). From 2 to 10 years after de-embankment (i.e. August 2002-2011), the annual SEC was on average $2.8,18.5$ and $7.2 \mathrm{~mm} /$ year in the high and low reference salt marshes and the grazed restored site, respectively.

\section{Effect of Tidal Flooding on SEC in the Reference Salt Marsh and the Restored Site}

The surface-elevation change had a positive linear relationship with flooding frequency in both the reference salt marsh and the restored site (Fig. 4(a, b): $a=-8.11, b=0.53, d f=299$, adj. $R^{2}=0.387, P=8.270 \mathrm{e}-34$ for the reference marsh, and $\mathrm{a}=-4.54, \mathrm{~b}=0.46, \mathrm{df}=138$, adj. $R^{2}=0.176, P=1.508 \mathrm{e}-07$ for the restored site). Though the range in flooding frequency in the restored site was smaller than in the reference salt marsh, the two relationships appeared almost identical with a clear

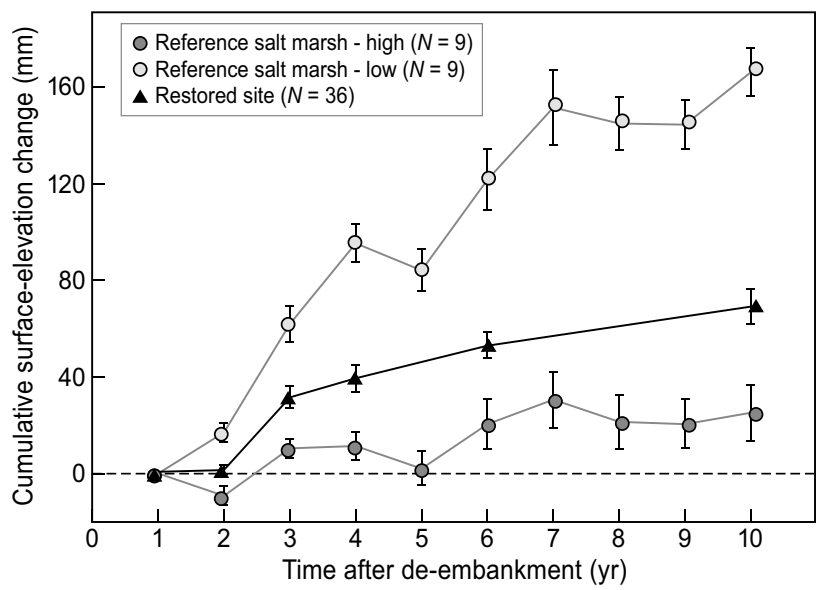

Fig. 3 Comparison of the cumulative surface-elevation change (SEC) in the restored site from 2 to 10 years after de-embankment, with SEC in the more seaward located low and high reference salt marsh (August measurements only). $N$, number of SEB points 
Fig. 4 The relationship between the annual surface-elevation change (SEC) and tidal frequency for a reference salt marsh and $\mathbf{b}$ the restored site. Furthermore, the relationship between the annual SEC and the annual cumulative height of the water column above the marsh surface ( $\mathrm{m} /$ year) for $\mathbf{c}$ the reference salt marsh and $\mathbf{d}$ the restored site. $* * * P<0.001$
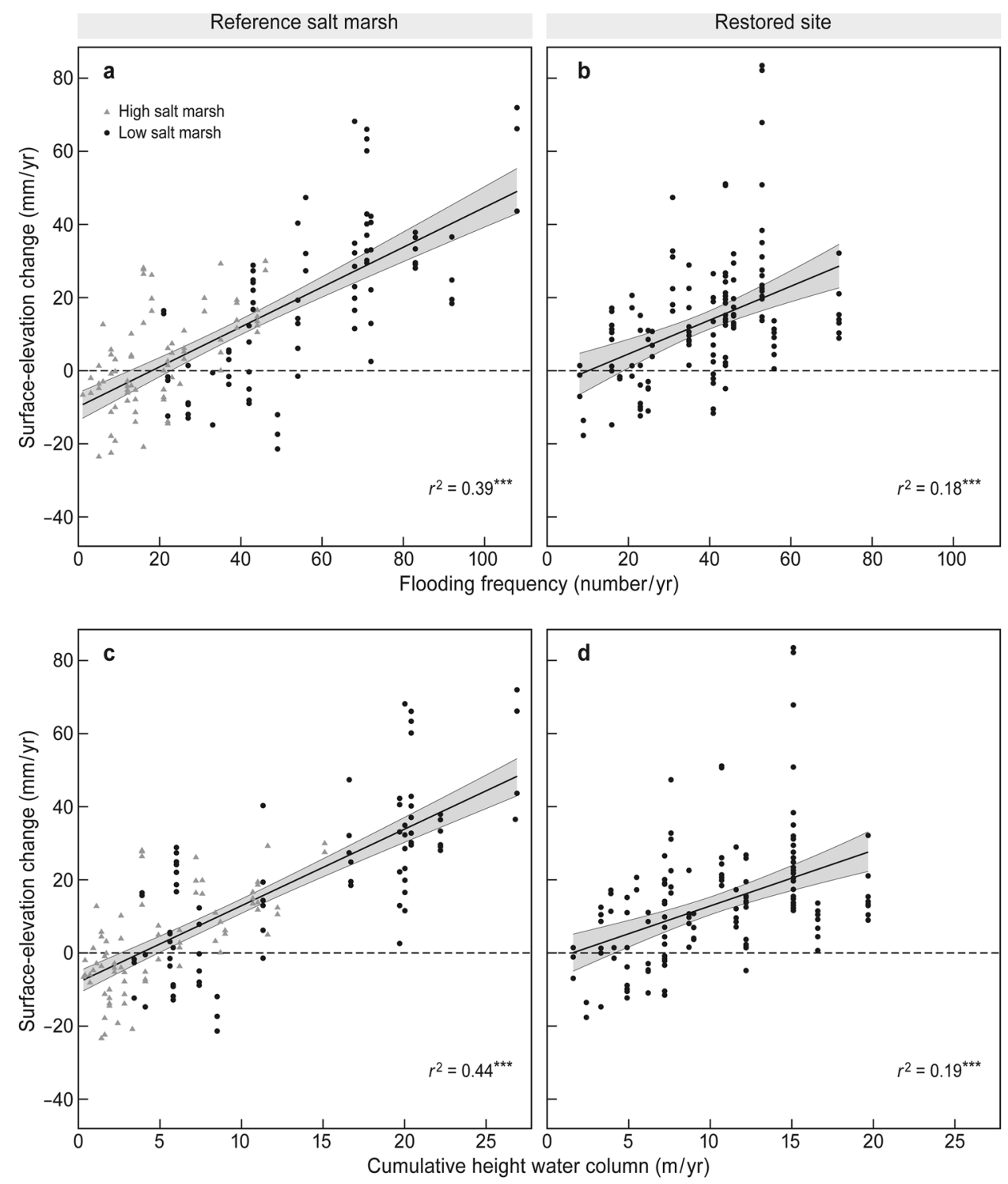

overlap of the two confidence intervals and a somewhat lower intercept with the vertical axis in the reference salt marsh.

SEC showed also a linear relationship with the CHWC in both sites (Fig. 4(c, d): $a=-6.57, b=1.93, d f=299$, adj. $R^{2}=0.443, P=3.744 \mathrm{e}-40$ for the reference salt marsh, and $\mathrm{a}=-2.30, \mathrm{~b}=1.52, \mathrm{df}=138$, adj. $R^{2}=0.192$, $P=3.720 \mathrm{e}-08$ for the restored site). Also, these relationships appeared almost the same with again a somewhat lower intercept with the vertical axis in the reference salt marsh. It is noteworthy that negative values of SEC occurred regularly in years with a low flooding frequency or CHWC values. This phenomenon explains the negative intercepts in Fig. 4 and underlines the significance of tidal flooding on sediment buildup in both reference salt marsh and the restored site.

\section{Spatial and Seasonal Differences in SEC in the Restored Site}

In the grazed areas, the annual or year-round SEC was higher and close to both breaches and creeks than farther away from breaches and creeks (Fig. 5(a): Kruskal-Wallis $\left.\mathrm{chi}^{2}=17.6, \mathrm{df}=3, P=0.0005\right)$. A similar result was found in the exclosures (Fig. 6(a): Kruskal-Wallis $\mathrm{chi}^{2}=21.1, \mathrm{df}=3$, $P=9.881 \mathrm{e}-05)$, although the pattern was less distinct compared to the grazed situation. 
In both grazed and ungrazed conditions, there was a clear-cut seasonal difference in SEC with positive values in winter versus negative values in summer (Figs. 5(b, c) and 6(b, c)). In grazed areas, SEC during winter was lowest and far from both breaches and creeks and relatively high at creek-near positions (Fig. 5(b): Kruskal-Wallis chi $\left.^{2}=10.9, \mathrm{df}=3, P=0.0124\right)$. Surprisingly, in the ungrazed exclosures, the station position in the sediment-supply route did not seem to have an effect on SEC in winter (Fig. 6(b): Kruskal-Wallis $\left.\mathrm{chi}^{2}=1.6, \mathrm{df}=3, P=0.6679\right)$, although the spatial pattern resembled that of the grazed areas. In summer, no differences in SEC were found between the station positions neither in grazed nor in ungrazed areas (Fig. 5(c): Kruskal-Wallis $\mathrm{chi}^{2}=1.1, \mathrm{df}=3, P=0.7653$, and Fig. 6(c): Kruskal-Wallis $\left.\mathrm{chi}^{2}=2.0, \mathrm{df}=3, P=0.5708\right)$.

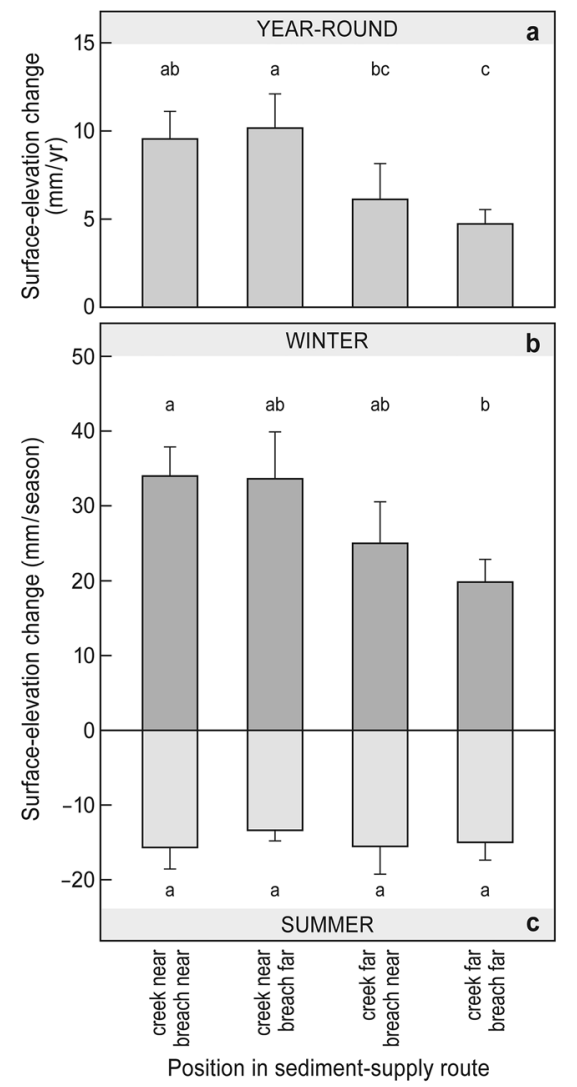

Fig. 5 Spatial variation in surface-elevation change (SEC) in relation to the station position in the sediment-supply route in the restored site under standard conditions in the area (i.e. summer grazing). a Annual SEC (mm/year) during years 2-10 after de-embankment. Seasonal SEC ( $\mathrm{mm} / \mathrm{season})$ in b winter and c summer during years 2-4 after de-embankment. Summer $=$ April-August; $\quad$ winter $=$ September March. Different letters indicate differences at $P<0.05$

\section{Effect of Livestock Grazing on SEC in the Restored Site}

During years 2-10 after de-embankment, the annual SEC was more than twice as high inside the exclosures compared to the grazed area (Fig. 7(a): Mann-Whitney $U=626$ and $P=2.2 \mathrm{e}-16$ ). Seasonal influences appeared to reinforce the difference in SEC between the grazed and exclosed marshes. In winter, SEC inside the exclosures was higher than in the grazed area (Fig. 7(b): Mann-Whitney $U=699$ and $P=6.127 \mathrm{e}-12$ ), although values were more or less in the same order of magnitude. In summer, SEC was negative in both the grazed and exclosed salt marshes with lower values in the grazed marsh (Fig. 7(c): Mann-Whitney $U=1694$ and $P=2.051 \mathrm{e}-12$ ), enhancing the difference between the grazed and exclosed marshes on an annual basis.

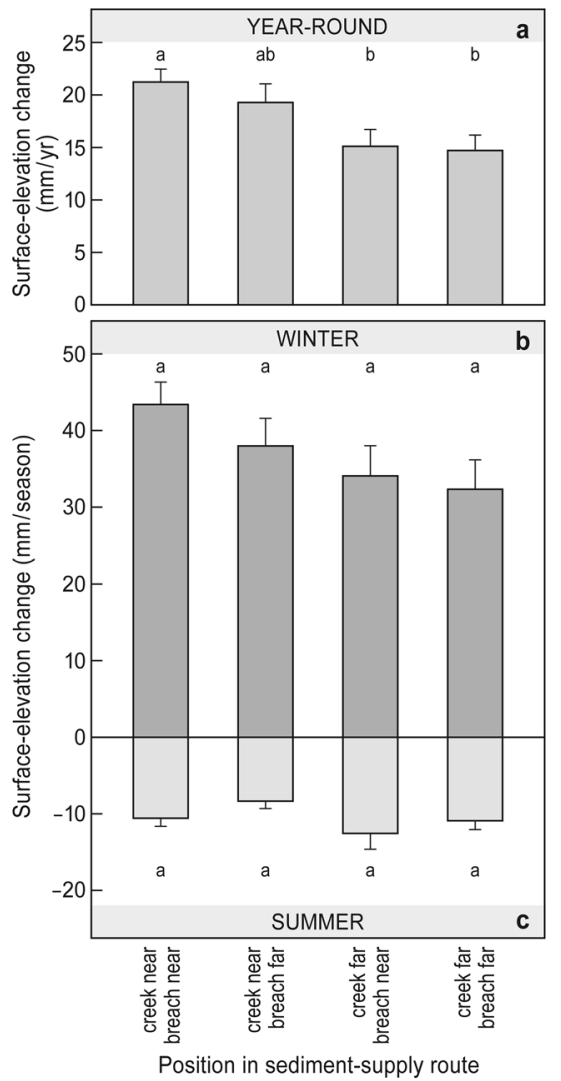

Fig. 6 Spatial variation in surface-elevation change (SEC) in relation to the station position in the sediment-supply route in the restored site in the ungrazed exclosures. a Annual SEC (mm/year) during years 2-10 after de-embankment. Seasonal SEC (mm/season) in b winter and c summer during years 2-4 after de-embankment. Summer $=$ April-August; winter $=$ September - March. Different letters indicate differences at $P<0.05$ 


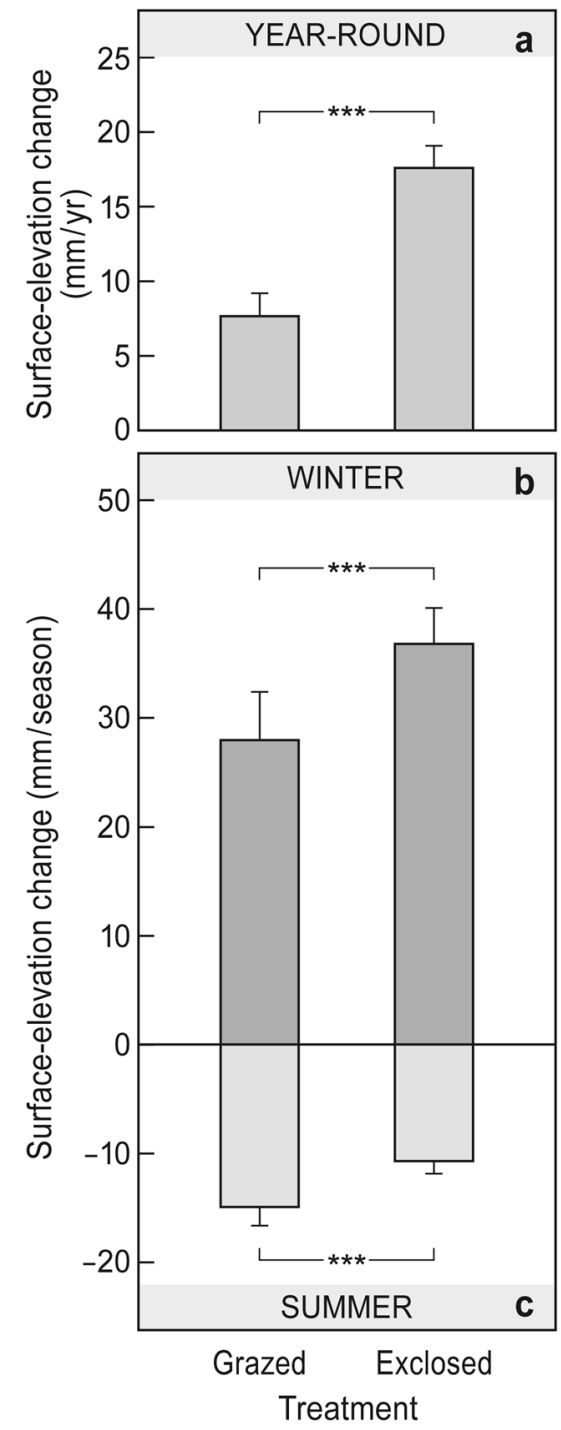

Fig. 7 The effect of grazing on surface-elevation change (SEC) in the restored site. a Annual SEC (mm/year) in the restored site during years 2-10 after de-embankment. Seasonal SEC ( $\mathrm{mm} / \mathrm{season})$ in b winter and c summer during years 2-4 after de-embankment. Summer $=$ April-August; winter $=$ September - March. $* * * P<0.001$

\section{Discussion}

\section{SEC in the Restored Site and Reference Salt Marsh}

The flooding frequency of summer polders is very limited (mostly less than once a year), due to the presence and crest height of the enclosing summer dikes. Not surprisingly, the few data available show that SEC in summer polders in the Wadden Sea is negligible (Esselink et al. 2017). Enhanced by local sea-level rise, the lack of sediment input during the period of embankment causes summer polders to develop an elevation deficit in respect to the tidal frame. This may be further enhanced by soil compaction in the polderized area (Wolters et al. 2005b). The combination of a local increase of MHT of $2.2 \mathrm{~mm} /$ year during the twentieth century, a period of embankment of 92 years, implies that our restored site developed an elevation deficit of at least $20 \mathrm{~cm}$ during its polder period (Esselink et al. 2015). This deficit is likely an underestimate, as it does not take into account soil compaction. During the first 10 years after de-embankment, about one-third $(7 \mathrm{~cm})$ of the elevation deficit was already compensated in the grazed conditions (Fig. 8). The outcome of the exclosure experiments shows that if grazing had been excluded, the compensation of the elevation deficit of the restored marsh could have been much greater, viz. $17 \mathrm{~cm}$ or about $80 \%$ during the first 10 years after de-embankment (Figs. 7(a) and 8). The latter value nearly matches the average value of $16 \mathrm{~cm}$ of other northwest European coastal re-alignment sites of the same age in the review of Wolters et al. (2005b). The catching up of the elevation deficit in our restored site indicates the apparent agreeable conditions for salt-marsh restoration by de-embanking summer polders at this stretch of the coast, despite the fact that the summer polders are not located directly next to the sea.

Conditions for the rapid reduction in the elevation deficit in salt-marsh restoration are likely to coincide with factors that determine resilience of salt marshes to sea-level rise. Kirwan et al. (2010, 2016) suggest that resilience of salt marshes to sea-level rise may strongly depend on the interplay between tidal range and suspended sediment concentration (SSC) of the tidal waters. Tidal range in the study area is $2.3 \mathrm{~m}$ (see "Methods"), whereas suspended matter concentration in this part of the Wadden Sea is relatively high with a long-term average of around $100 \mathrm{mg} / \mathrm{dm}^{3}$ (based on monitoring by Rijkswaterstaat at the nearshore Dantziggat station (N 53⒉ 4.068 , E $5^{\circ} 43.619$ ); De Vries et al. 2018). This value matches the maximum value of the range considered by Kirwan et al. (2010, 2016) and confirms the favourable condition for sediment buildup in salt marshes in the area.

Because sediment buildup in the adjacent salt marsh continued during the period of embankment, the elevation deficit also caused the summer polder and consequently also the restored site to develop into a depression on the landward site of the high marsh (Fig. 8). The relative elevation difference of $18 \mathrm{~cm}$ was partly compensated during the first 10 years after de-embankment because SEC in the restored site exceeded SEC in the high salt marsh (Fig. 3). We nevertheless do not expect that surface elevation of the restored site will equalize with the surface elevation of the high marsh. Other restored sites in northwestern Europe show decreased SEC over time since deembankment because of declining vertical accretion when soil surface approaches the mean sea level (Wolters et al. 2005b). The annual SEC of $7 \mathrm{~mm} /$ year in the restored site 
is in the range of other studies in north-west Europe with rates between 3 and $25 \mathrm{~mm} /$ year during the first 10 years after de-embankment (Wolters et al. 2005b). SEC of our restored site may be at the lower end of this range as it was grazed, whereas most other sites in the review of Wolters et al. (2005b) were not grazed.

\section{Effect of Tidal Flooding on SEC}

The flooding frequency and CHWC depend on surface elevation. Because the similarity between the restored site and the reference salt marsh in SEC, surface elevation explains the intermediate value of the cumulative SEC in the restored site compared to the low and high reference salt marshes (Fig. 3). The annual SEC in both the reference salt marsh and the restored site showed a positive linear relationship with tidal flooding, i.e. flooding frequency and CHWC (Fig. 4). The relationship between SEC and the flooding frequency (Fig. 4(a, b)) and CHWC (Fig. 4(c, d)) was similar for the reference marsh and the restored site. This suggests that the distance between the restored site and the intertidal flats (sea) showed no negative effect on SEC, in contrast to French and Spencer (1993). This difference could be due to the very high SSC in our study area. The latter study mentions higher accretion rates near the seaward marsh edge. Vertical accretion was found to be positively related to storm frequency and water depth, i.e. mean height of these storm tides (Schuerch et al. 2012), in line with our results. Moreover, Schuerch et al. (2012) found that the effects of storm frequency and water depth differ within a salt marsh. In a low-marsh zone, which is subject to deeper water columns, the mean storm strength is the major factor affecting marsh accretion, whereas in the high-marsh zone with thinner water columns, it is storm frequency that impacts marsh accretion (Schuerch et al. 2012). Higher elevation is inundated shorter and less frequently, which leads to a lower inundation duration as well as a lower water column with which sediment can be deposited (French and Spencer 1993; Allen 2000; Bartholdy et al. 2004; Schuerch et al. 2018).

Leonardi et al. (2018) summarized studies on the effects of the strength of storms on marsh sedimentation. Moderate storm events appear to be responsible for the majority of marsh sedimentation on the Danish peninsula of Skallingen (Bartholdy et al. 2004), where extreme storm events were shown to increase suspended sediment concentrations within the adjacent tidal basin by a factor of up to 20 due to sediment resuspension on the intertidal mudflats. There, a single extreme storm event could contribute $7.5 \%$ to the annual sediment deposition, whereas a single regularly occurring mild storm already contributed $71 \%$ (Bartholdy and Aagaard 2001). The explanation for this pattern is that the frequency of high and extreme water levels decreases exponentially with increasing high water levels (Bartholdy et al.
2004; Schuerch et al. 2013), whereas the sediment resuspension on the intertidal mudflat appears to follow a linear relationship with the increasing high water level (Temmerman et al. 2003). The composition of suspended sediment might also play a role. The finest fraction will settle slowly; hence, long duration of flooding seems important. The coarser fraction will deposit faster; hence, flooding frequency seems more important than duration. As the latter fraction harbors bigger particles, it will contribute most to sediment buildup.

\section{Seasonal and Spatial Differences in SEC in Restored Site}

In the restored site, the positive values of SEC during winter were in sharp contrast with the negative values during summer (Figs. 5, 6 and 7). The negative SECs seem a characteristic summer phenomenon, which can be related to the lack of sediment input by the almost complete absence of tidal flooding in combination with shrinkage due to evaporation. Summer grazing may add up to the negative SEC due to compaction by trampling (Fig. 7(c); Nolte et al. 2015). For two reasons, erosion probably contributed little to the loss of elevation in summer. Firstly, the restored site remained vegetation covered from the start of de-embankment (see study area and Chang et al. 2016). As there was no bare soil, erosion by ebb flow as reported by Reef et al. (2018) in poorly vegetated salt marsh is unlikely. Secondly, the virtual absence of tidal flooding in summer excludes erosion to play a significant role in this season.

Summer elevation losses of $10-15 \mathrm{~mm} /$ year in the present study are in line with the values found in other studies in foreland salt marshes in the Wadden Sea (Erchinger et al. 1996; Nolte et al. 2015; Elschot et al. 2020), but they contrast with the values found in the Wadden Sea back-barrier marshes, where accretion rates are much lower (Esselink et al. 2017), and summer losses in SEC may be limited to about $1 \mathrm{~mm} /$ year (Van Wijnen and Bakker 2001; Schuerch et al. 2012). Short-term (i.e. daily to seasonal) fluctuations in soil hydrology may affect elevation changes in wetlands by both shrinkage and swell (Paquette et al. 2004; Cahoon et al. 2006). To which extent summer shrinkage in the Wadden Sea salt marshes may be reversed by winter swell is not known. Even when swell would equal shrinkage, sediment buildup is the dominant factor for SEC in winter. The positive values in winter may be attributed to that tidal flooding is concentrated during this period (Veeneklaas et al. 2015), in line with other studies (Stumpf 1983; French and Spencer 1993; Van Duin et al. 1997; Allen 2000). We conclude that the negative values of SEC during summer are related to evaporation with an additive effect of trampling when the marsh is grazed (Fig. 7(c)). This seasonal pattern in SEC and the positive cumulative SEC over the years in this study are in line with other studies in European salt marshes (Erchinger et al. 1996; Van der Wal and Pye 2004; Elschot et al. 2020). 
Fig. 8 Cross section of the foreland in Noord-Friesland Buitendijks, from the intertidal flat to the main seawall at the start of the experiment in 2001, with sea-level and surface-elevation change (SEC) in the different parts during the first 10 years after the de-embankment of a summer polder (restored salt marsh). Both the reference salt marsh and the restored site were grazed by livestock. Based on the exclosure experiments, the broken line gives the SEC in absence of grazing (modified from Esselink et al. 2015) (online version in colour)

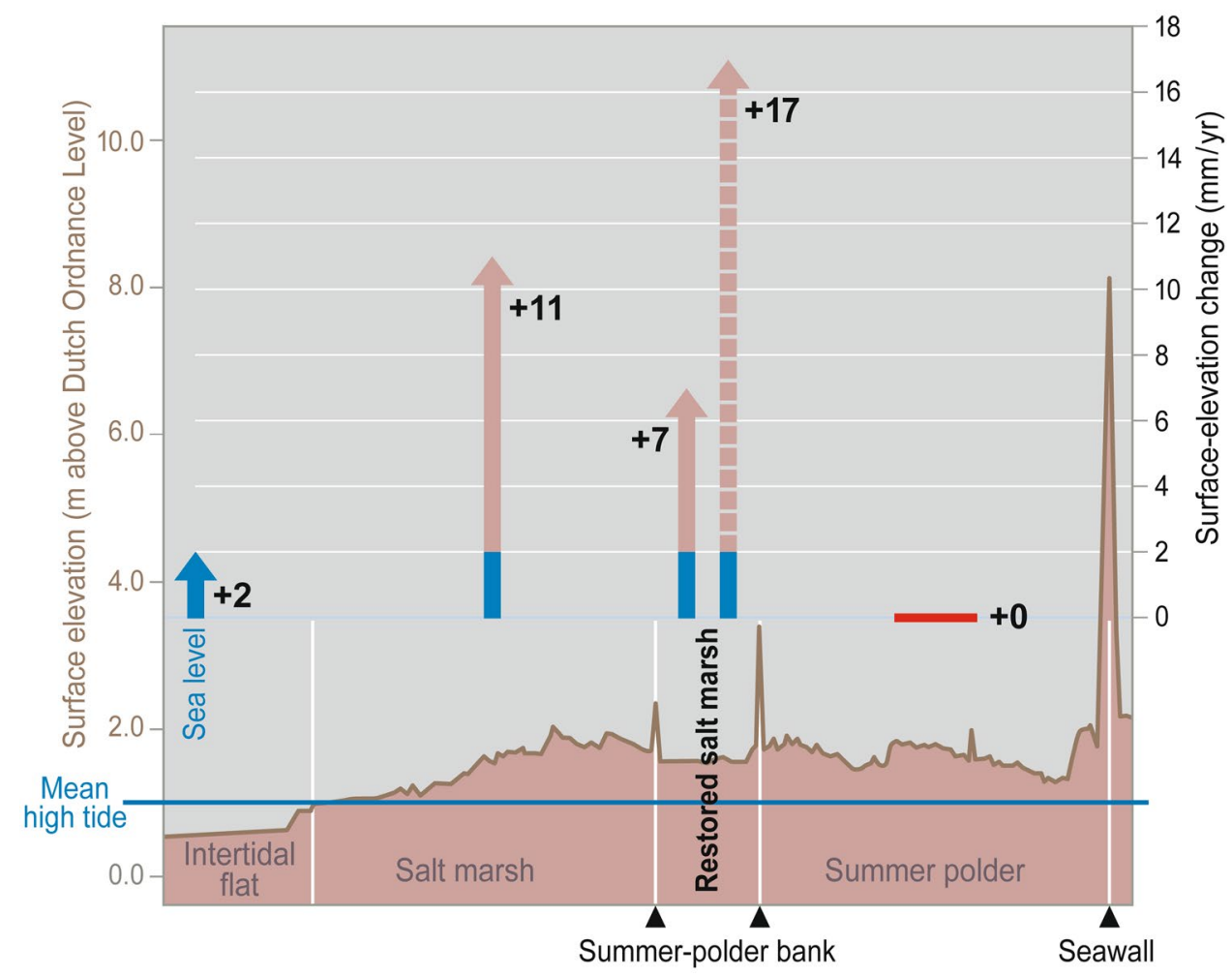

Summer-polder bank sediment input in the restored site. In wide salt marshes, SEC generally decreases landward with the increasing distance from the marsh edge (Esselink et al. 1998; Schröder et al. 2002; Bakker et al. 2016). Compensation of the elevation deficit by sediment buildup in the more landward-located summer polders may therefore occur more slowly in comparison with our restored site, which showed similar SEC as the reference salt marsh. If these remaining polders are de-embanked, we would recommend to employ much wider breaches or complete removal of the summer dike. The observed high sedimentation rates will likely allow the establishment of new salt marshes. However, there are benefits to maintaining parts of a dike for flood protection purposes in case of low sedimentation rates (Zhu et al. 2020).

\section{The Impact of Grazing on SEC in the Restored Site}

Livestock grazing had a negative effect on the annual SEC in the restored site (Fig. 7(a)). This is in line with other studies on grazing in salt marshes (Erchinger et al. 1996; Neuhaus et al. 1999; Elschot et al. 2013). The division of the annual SEC into seasonal changes indicates that differences in SEC between grazed and ungrazed conditions are based on two interacting factors (Fig. 7(b, c)). Firstly, the higher SEC inside the exclosures during winter (when livestock is also absent in the grazed marsh) implies that more sediments were deposited inside the exclosures. This may be an effect of the taller ungrazed vegetation inside the exclosures, and hence a higher surface roughness, and lower water turbidity during flooding tion of the three local breaches could have resulted in a higher 
(Möller 2006; Temmerman et al. 2012). This effect, however, may fade out over time when the herbaceous vegetation (Chang et al. 2016) is weathered or becomes flattened by sediments during winter. Consequently, differences in vegetation structure between inside and outside the exclosures decrease during winter, which may explain the moderate difference of SEC between the grazed and ungrazed marshes. Secondly, in the grazed salt marsh, summer trampling by livestock enhances compaction (Schrama et al. 2013; Nolte et al. 2013b; Elschot et al. 2015), which will likely be the main cause for the greater negative values of SEC in the grazed marsh compared to the exclosed marsh in this season (Fig. 7(c)).

\section{Long-term Management}

Breaching the summer dike of a former summer polder is an effective method for long-term salt-marsh restoration in a system dominated by sediment input. The elevation deficit that developed in the restored site during the 92-year period of embankment was already compensated by $35 \%$ in 10 years' time. Incoming salt water resulted in salinization (Veeneklaas et al. 2015). Hence, characteristic salt-marsh plant communities of the low and high salt marshes became established a few years after breaching (Chang et al. 2016). Establishment of halophytic species was recorded after 1 year in the restoration sites in the UK, however with early successional species remaining dominant until 14 years after breaching (Mossman et al. 2012a). Overall community composition of accidentally realigned (25-131 years old) sites was similar to the reference marshes, however with relatively rare characteristic perennial plant species. In contrast, the shrub Atriplex portulacoides was more abundant, and its growth form may inhibit or delay colonization by other species (Mossman et al. 2012b). These UK sites were not grazed by livestock, whereas in a review of 70 sites in NW Europe, grazing turned out to be important to prevent dominance of a single species (Wolters et al. 2005a, b).

Topographic heterogeneity is an important prerequisite for a diverse marsh. De-embanked sites are drained and have often been leveled for agricultural purposes, however. Such restored sites are not automatically on a trajectory to become topographically similar to natural marshes (Lawrence et al. 2018). Breaches and accompanying dug creeks induced spatial variation in sediment buildup and hence enhance potential for vegetation diversity. Grazing by livestock resulted in lower SEC than in the exclosures. To increase the SEC rate of the site, grazing might be excluded during the first phase after de-embankment. At a later stage, an adaptive grazing management may be introduced depending on marsh elevation, vegetation development and conservation aims (Veeneklaas et al. 2013; Chang et al. 2016; Van Klink et al. 2016). More experiments on effects of grazers by exclosures and enclosures are advocated (Zedler 2017).

Restoration in a system with a large contribution of plant material in SEC shows another pattern. Peat marshes in the
USA did not show a deficit in surface elevation, but subsided as much as $40-50 \mathrm{~cm}$ after periods of $25-50$ years of embankment. Subsidence was caused by lowering of the water table with subsequent oxidation of the peat and lowering of the soil surface. Restoration by opening gates resulted within 10 years in recovery of the halophytic species. Recovery of subsidence with distinction between new peat formation and sediment input was not monitored (Niering 1997). No information is available on restoration with respect to compensation for deficits in soil elevation after diking. Most studies focus on halophytic plant and animal assemblages (Zedler 2017).

Acknowledgements This study was performed in collaboration with It Fryske Gea. Gerrit van der Leest and Johannes Westerhof monitored and maintained the functioning of the exclosures for 10 years after de-embankment. Over the years, many people participated in the fieldwork. We thank Aad Sleutel, Koos Zegers and Piet-Wim van Leeuwen (WMR) for their support with the installation of the SEB-measuring points and their assistance in the SEB measurements. Dick Visser prepared the figures. Johan Hidding advised on the analyses of Fig. 4. We thank two anonymous reviewers and the editor for constructive comments.

Funding This study forms a synthesis of accumulated projects that were financially supported by the Waddenfonds, It Fryske Gea, the Prins Bernhard Cultuurfonds, Rijkswaterstaat Noord-Nederland, the EU Life-Nature Programme and the former Dutch Ministry of Agriculture, Nature and Food Quality.

Data Availability Data will be uploaded and available from the University of Groningen Data Repository Dataverse Network, https://doi. org/10.34894/6D56NS.

Open Access This article is licensed under a Creative Commons Attribution 4.0 International License, which permits use, sharing, adaptation, distribution and reproduction in any medium or format, as long as you give appropriate credit to the original author(s) and the source, provide a link to the Creative Commons licence, and indicate if changes were made. The images or other third party material in this article are included in the article's Creative Commons licence, unless indicated otherwise in a credit line to the material. If material is not included in the article's Creative Commons licence and your intended use is not permitted by statutory regulation or exceeds the permitted use, you will need to obtain permission directly from the copyright holder. To view a copy of this licence, visit http://creativecommons.org/licenses/by/4.0/.

\section{References}

Adam, P. 1990. Saltmarsh ecology. Cambridge: Cambridge University Press. Adam, P., M.D. Bertness, A.J. Davy, and J.B. Zedler. 2008. Saltmarsh. In Aquatic ecosystems, ed. N.V.C. Polunin, 157-171. Cambridge: Cambridge University Press.

Allen, J.R.L. 2000. Morphodynamics of Holocene salt marshes: a review sketch from the Atlantic and Southern North Sea coasts of Europe. Quarterny Science Review 19: 1155-1231.

Bakker, J.P., A.C.W. Baas, J. Bartholdy, L. Jones, G. Ruessink, and S. Temmerman. 2016. Environmental impacts - coastal ecosystems. In North Sea region climate change assessment. Regional climate studies, ed. M. Quante and F. Colijn, 275-314. Springer International Publishing AG Switzerland. 
Bartholdy, J., and T. Aagaard. 2001. Storm surge effects on a back-barrier tidal flat of the Danish Wadden Sea. Geo-Marine Letters 20: 133-141.

Bartholdy, J., C. Christiansen, and H. Kunzendorf. 2004. Long term variations in backbarrier salt marsh deposition on the Skallingen peninsula - the Danish Wadden Sea. Marine Geology 203: 1-21. https://doi.org/10.1016/S0025-3227(03)00337-2.

Bartholdy, A.T., J. Bartholdy, and A. Kroon. 2010. Salt marsh stability and patterns of sedimentation across a backbarrier platform. Marine Geology 278: 31-42. https://doi.org/10.1016/j.margeo.2010.09.001.

Bertness, M.D. 1999. The ecology of Atlantic shorelines. Sunderland: Sinauer Associates.

Boumans, R.M.J., and J.W. Day. 1993. High precision measurements of sediment elevation in shallow coastal areas using a sedimentationerosion table. Estuaries 16: 375-380.

Brooks, K.L., H.L. Mossman, J.L. Chitty, and A. Grant. 2015. Limited vegetation development on a created salt marsh associated with over-consolidated sediments and lack of topographic heterogeneity. Estuaries and Coasts 38: 325-336. https://doi.org/10.1007/ s12237-014-9824-3.

Cahoon, D.R., D.J. Reed, and J.W. Day. 1995. Estimating shallow subsidence in microtidal salt marshes of the southeastern United States: Kaye and Barghoorn revisited. Marine Geology 128: 1-9.

Cahoon, D.R., P.F. Hensel, T. Spencer, D.J. Reed, K.J. McKee, and N. Saintilan. 2006. Coastal wetland vulnerability to relative sea-level rise: wetland elevation trends and process controls. In Wetland and natural resource management. Ecological studies 190, ed. J.T.A. Verhoeven, B. Beltman, R. Bobbink and D.E. Whigham, 271-292. Berlin: Springer.

Chang, E.R., R.M. Veeneklaas, J.P. Bakker, P. Daniels, and P. Esselink. 2016. What factors determine restoration success of a salt marsh ten years after de-embankment? Applied Vegetation Science 19: 66-77.

CWSS. 2010. Wadden Sea Plan 2010. Wilhelmshaven: Common Wadden Sea Secretariat.

Davidson, K.E., M.S. Fowler, M.W. Skov, S.H. Doerr, N. Beaumont, and J.N. Griffin. 2017. Livestock grazing alters multiple ecosystem properties and services in salt marshes: a meta-analysis. Journal of Applied Ecology 54: 1395-1405. https://doi.org/10.1111/13652664.12892.

Davy, A.J, J.P. Bakker, and M.E. Figueroa. 2009. Human modification of European salt marshes. In Human impacts on salt marshes: a global perspective., ed. B.R. Silliman, E.D. Grosholz, and M.D. Bertness, 311-335. Berkely: University of California Press.

De Groot A.V., R.M. Veeneklaas, and J.P. Bakker. 2011. Sand in the salt marsh: contribution of high-energy conditions to salt-marsh accretion. Marine Geology 282(3-4):240-254. https://doi.org/ 10.1016/j.margeo.2011.03.002.

De Vries, B., P. Dankers, and J. Vroom. 2018. Slib in de Waddenzee. een analyse en verklaring van de langjarige fluctuaties van sedimentconcentraties in water en bodem i.h.k.v. project KRW slib. Report. Nijmegen: Royal Haskoning DHV.

Dijkema, K.S. 1983. Use and management of mainland salt marshes and halligen. In Flora and vegetation of the Wadden Sea islands and coastal areas, ed. K.S. Dijkema and W.J. Wolff, 302-312. Rotterdam: Balkema.

Dijkema, K.S. 1987. Changes in salt-marsh area in the Netherlands Wadden Sea after 1600. In Vegetation between land and sea, ed. A.H.L. Huiskes, C.W.P.M. Blom, and J. Rozema, 42-49. Dordrecht: Dr. W. Junk Publishers.

Dijkema, K.S. 1997. Impact prognosis for salt marshes from subsidence by gas extraction in the Wadden Sea. Journal of Coastal Research 13: $1294-1304$.

Elschot, K., T.J. Bouma, S. Temmerman, and J.P. Bakker. 2013. Effects of long-term grazing on sediment deposition and salt-marsh accretion rates. Estuarine, Coastal and Shelf Science 133: 109-115. https:// doi.org/10.1016/j.ecss.2013.08.021.
Elschot, K., J.P. Bakker, S. Temmerman, J. Van de Koppel, and T.J. Bouma. 2015. Ecosystem engineering by large grazers enhances carbon stocks in a tidal salt marsh. Marine Ecology Progress Series 537: 9-21.

Elschot, K., M.E.B. Van Puijenbroek, D.D.G. Lagendijk, J-T. Van der Wal, and C. Sonneveld (2020). Lange-termijnontwikkeling van kwelders in de Waddenzee (1960-2018). Wettelijke Onderzoekstaken Natuur \& Milieu, WOt-technical report 182/ Wageningen Marine Research rapport $\mathrm{C} 023 / 20$.

Erchinger, H.F., H.G. Coldewey, and C. Meyer. 1996. Interdisciplinäre Erforschung des Deichvorlandes im Forschungsvorhaben Erosionsfestigkeit von Hellerns. Die Küste 58: 1-45.

Esselink, P., and E.R. Chang. 2010. Kwelderherstel Noard-Fryslân Bûtendyks: invloed van stormactiviteit op zes jaar proefverkweldering. PUCCIMARrapport 01. Vries: PUCCIMAR Ecologisch Onderzoek \& Advies.

Esselink, P., K.S. Dijkema, S. Reents, and G. Hageman. 1998. Vertical accretion and profile changes in abandoned man-made tidal marshes in the Dollard estuary, the Netherlands. Journal of Coastal Research 14: $570-582$.

Esselink, P., D. Bos, P. Daniels, W.E. van Duin, and R.M. Veeneklaas. 2015. Van Polder naar kwelder: tien jaar kwelderherstel Noarderleech. PUCCIMAR rapport 06. Vries: PUCCIMAR Ecologisch Onderzoek \& Advies.

Esselink, P., W.E. Van Duin, J. Bunje, J. Cremer, E.O. Folmer, J. Frikke, M. Glahn, A.V. De Groot, N. Hecker, U. Hellwig, K. Jensen, P. Körber, J. Petersen, and M. Stock. 2017. Salt marshes. In Wadden Sea Quality Status Report 2017, eds Kloepper, S. et al. Wilhelmshaven. Last updated 21.12.2017. Downloaded 17.01.2019. qsr. waddensea-worldheritage.org/reports/salt-marshes.

French, J. 2006. Tidal marsh sedimentation and resilience to environmental change: exploratory modelling of tidal, sea-level and sediment supply forcing in predominantly allochthonous systems. Marine Geology 235: 119-136. https://doi.org/10.1016/j.margeo. 2006.10.009.

French, J.R., and T. Spencer. 1993. Dynamics of sedimentation in a tide-dominated backbarrier salt marsh, Norfolk, UK. Marine Geology 110: 315-331.

French, P.W. 1999. Managed retreat : a natural analogue from the Medway estuary, UK. Ocean and Coastal Management 42: 49-62.

French, P.W. 2006. Managed realignment - the developing story of a comparatively new approach to soft engineering. Estuarine Coastal Shelf Science 67: 409-423.

Kirwan, M.L., G.R. Guntenspergen, A. D’Alpaos, J.T. Morris, S.M. Mudd, and S. Temmerman. 2010. Limits on the adaptability of coastal marshes to rising sea level. Geophysical Research Letters 37: L23401. https://doi.org/10.1029/2010GL045489.

Kirwan, M.L., S. Temmerman, E.E. Skeehan, and G.R. Guntenspergen. 2016. Overestimation of marsh vulnerability to sea level rise. Nature Climate Change 6: 253-260. https://doi.org/10.1038/nclimate2909.

Lawrence, P.J., G.R. Smith, M.J.P. Sullivan, and H.J. Mossman. 2018. Restored saltmarshes lack the topographic diversity found in natural habiata. Ecological Engineering 115: 58-66. https://doi.org/10. 1016/j.ecoleng.2018.02.007.

Leonard, L.A. 1997. Controls of sediment transport and deposition in an incised mainland marsh basin, southeastern North Carolina. Wetlands 17: 263-274.

Leonardi, N., I. Carnacina, C. Donatelli, N.K. Ganju, A.J. Plater, M. Schuerch, and S. Temmerman. 2018. Dynamic interactions between coastal storms and salt marshes: a review. Geomorphology 301: 92-107. https://doi.org/10.1016/j.geomorph.2017.11.001.

Möller, I. 2006. Quantifying saltmarsh vegetation and its effect on wave height dissipation: results from a UK East coast saltmarsh. Estuarine, Coastal and Shelf Science 69: 337-351. https://doi.org/ 10.1016/j.ecss.2006.05.003.

Mossman, H.L., A.J. Davy, and A. Grant. 2012a. Does managed coastal realignment create saltmarshes with 'equivalent biological 
characteristics' to natural reference sites? Journal of Applied Ecology 49: 1446-1456.

Mossman, H.L., M.J.H. Brown, A.J. Davy, and A. Grant. 2012b. Constraints on salt marsh development following managed coastal realignment: dispersal limitation or environmental tolerance? Restoration Ecology 20: 65-75. https://doi.org/10.1111/j.1526100X.2010.00745.x.

Neuhaus, R., T. Stelter, and K. Kiehl. 1999. Sedimentation in saltmarshes affected by grazing regime, topographical patterns and regional differences. Senckenbergiana Maritima 29: 113-116.

Niering, W.A. 1997. Tidal wetlands restoration and creation along the east coast of North America. In: Restoration ecology and sustainable development, Eds. Urbanska, K,M. N.R. Webb, and P.J. Edwards, pp 259-285. Cambridge University Press, Cambridge.

Nolte, S., E.C. Koppenaal, P. Esselink, K.S. Dijkema, M. Schuerch, A.V. De Groot, J.P. Bakker, and S. Temmerman. 2013a. Measuring sedimentation in tidal marshes: a review on methods and their applicability in biogeomorphological studies. Journal of Coastal Conservation 17: 301-325. https://doi.org/10.1007/s11852-013-0238-3.

Nolte, S., F. Müller, M. Schuerch, A. Wanner, P. Esselink, J.P. Bakker, and K. Jensen. 2013b. Does livestock grazing influence salt marsh resilience to sea-level rise in the Wadden Sea? Estuarine Coastal and Shelf Sciences 135: 296-305.

Nolte, S., P. Esselink, J.P. Bakker, and C. Smit. 2015. Effects of livestock species and stocking density on accretion rates in grazed salt marshes. Estuarine, Coastal and Shelf Science 152: 109-115.

Pagès, J.F., S.R. Jenkins, T.J. Bouma, E. Sharps, and M.W. Skov. 2019. Opposing indirect effects of domestic herbivores on saltmarsh erosion Ecosystems 22:1055-1068. https://doi.org/10.1007/ s10021-018-0322-5.

Paquette, C.H., K.L. Sundberg, R.M.J. Boumans, and G.L. Chmura. 2004. Changes in saltmarsh surface elevation due to variability in evapotranspiration and tidal flooding. Estuaries 27: 82-89.

Pohlert T. 2014. The pairwise multiple comparison of mean ranks package (PMCMR). R package, <URL: https://CRAN.R-project. org $/$ package $=$ PMCMR $>$.

R Core Team. 2019. R: a language and environment for statistical computing. Vienna: R Foundation for Statistical Computing. URL:https://www.R-project.org/

Reed, D.J., T. Spencer, A.L. Murray, J.R. French, and L.A. Leonard. 1999. Marsh surface sediment deposition and the role of tidal creeks: implications for created and managed coastal marshes. Journal of Coastal Conservation 5: 81-90.

Reef, R., M. Schuerch, E.K. Chrisie, I. Möller, and T. Spencer. 2018. The effect of vegetation height and biomass on the sediment budget of a European saltmarsh. Estuarine, Coastal and Shelf Science 202: 125-133. https://doi.org/10.1016/j.ecss.2017.12.016.

Reise, K. 2005. Coast of change: habitat loss and transformations in the Wadden Sea. Helgoland Marine Research 59: 9-21. https:// doi.org/10.1007/s10152-004-0202-6.

Schrama, M., P. Heijning, J.P. Bakker, H.J. van Wijnen, M.P. Berg, and H. Olff. 2013. Herbivore trampling as an alternative pathway for explaining differences in nitrogen mineralization in moist grasslands. Oecologia 172: 231-243. https://doi.org/10.1007/s00442-012-2484-8.

Schröder, H.K., K. Kiehl, and M. Stock. 2002. Directional and nondirectional vegetation changes in a temperate salt marsh in relation to biotic and abiotic factors. Applied Vegetation Science 5: 33-44.

Schroor, M. 2009. Van Keeg en Leeg. Geschiedenis van het Noorderleegs-Buitenveld. Olterterp: It Fryske Gea.

Schuerch, M., J. Rapaglia, V. Liebetrau, A. Vafeidis, and K. Reise. 2012. Salt marsh accretion and storm tide variation: an example from a barrier island in the North Sea. Estuaries and Coasts 35: 486-500. https://doi.org/10.1007/s12237-011-9461-z.

Schuerch, M., A. Vafeidis, T. Slawig, and S. Temmerman. 2013. Modeling the influence of changing storm patterns on the ability of a salt marsh to keep pace with sea level rise. Journal of Geophysical Research: Earth Surface 118: 84-96. https://doi.org/10.1029/2012JF002471.

Scheurch, M., T. Dolch, J. Bisgwa, and A.T. Vafeidis. 2018. Changing sediment dynamics of a mature backbarrier salt marsh in response to sea-level rise and storm events. Frontiers in Marine Science. 5 (155): 1-14. https://doi.org/10.3389/fmars.2018.00155.

Shepard, C.C., C.M. Crain, and M.W. Beck. 2011. The protective role of coastal marshes: a systematic review and meta-analysis. PLOS ONE 6 (11): e27374. https://doi.org/10.1371/journal.pone.0027374.

Stumpf, R.P. 1983. The process of sedimentation on the surface of a salt-marsh. Estuarine Coastal and Shelf Science 17: 495-508.

Temmerman, S., G. Govers, S. Wartel, and P. Meire. 2003. Spatial and temporal factors controlling short-term sedimentation in a salt and freshwater tidal marsh, Scheldt Estuary, Belgium, SW Netherlands. Earth Surface Processes and Landforms 28: 739-755. https://doi. org/10.1002/esp.495.

Temmerman, S., P. Moonen, J. Schoelynck, G. Govers, and T.J. Bouma. 2012. Impact of vegetation die-off on spatial flow patterns over a tidal marsh. Geophysical Research Letters 39: L03406. https://doi. org/10.1029/2011GL050502.

Veeneklaas, R.M., K.S. Dijkema, N. Hecker, and J.P. Bakker. 2013. Spatiotemporal dynamics of the invasive plant species Elytrigia atherica on natural salt marshes. Applied Vegetation Science 16: 205-216. https:// doi.org/10.1111/j.1654-109X.2012.01228.x.

Veeneklaas, R.M., E.C. Koppenaal, J.P. Bakker, and P. Esselink. 2015. Salinization during salt-marsh restoration after managed realignment. Journal of Coastal Conservation 19: 405-415.

Vos, P.C., and E. Knol. 2015. Holocene landscape reconstruction of the Wadden Sea area between Marsdiep and Weser. Explanation of the coastal evolution and visualization of the landscape development of the northern Netherlands and Niedersachsen in five palaeogeographical maps from $500 \mathrm{BC}$ to present. Netherlands Journal of Geosciences 94: 157-183. https://doi.org/10.1017/njg.2015.4.

Van Duin, W.E., K.S. Dijkema, and J. Zegers. 1997. Veranderingen in bodemhoogte (opslibbing, erosie en inklink) in de Peazemerlannen. Wageningen: IBN-report 326.

Van Klink, R., S. Nolte, F. Mandema, G. Lagendijk, M.F. WallisDeVries, P. Esselink, J.P. Bakker, and C. Smit. 2016. Optimising grazing management for biodiversity conservation across trophic groups - effects of livestock species and stocking density on salt marshes. Agriculture, Ecosystems and Environment 235: 329-339.

Van der Wal, D., and K. Pye. 2004. Patterns, rates and possible causes of saltmarsh erosion in the Greater Thames area (UK). Geomorphology 61: 373-391. https://doi.org/10.1016/j.geomorph.2004.02.005.

Van Wijnen, H., and J.P. Bakker. 2001. Long-term surface elevation change in salt marshes: a prediction of marsh response to future sea-level rise. Estuarine, Coastal and Shelf Science 52: 381-390. https://doi.org/10.1006/ecss.2000.0744.

Wolters, M., J.P. Bakker, M.D. Bertness, R.L. Jefferies, and I. Möller. 2005a. Saltmarsh erosion and restoration in south-east England: squeezing the evidence requires realignment. Journal of Applied Ecology 42: 844-851. https://doi.org/10.1111/j.1365-2664.2005.01080.xER.

Wolters, M., R.A. Garbutt, and J.P. Bakker. 2005b. Salt-marsh restoration: evaluating the success of de-embankments in north-west Europe. Biological Conservation 123: 249-268. https://doi.org/10.1016/j. biocon.2004.11.013.

Zar, J.H. 1996. Biostatistical analyses. London: Prentice Hall.

Zedler, J.B. 2017. What's new in adaptive management and restoration of coasts and estuaries? Estuaries and Coasts 40: 1-21. https:// doi.org/10.1007/s12237-016-0162-5.

Zhu, Z., V. Vuik, P.J. Visser, T. Soens, B. Van Wesenbeeck, J. Van de Koppel, S.N. Jonkman, S. Temmerman, and T.J. Bouma. 2020. Historic storms and the hidden value of coastal wetlands for nature-based flood defence. Nature. Sustainability 3: 853-862. https://doi.org/10.1038/s41893-020-0556-z. 